\title{
Effects of combined therapy in celullitis: controlled clinical trial, randomized and blind
}

Ingrid Jullyane Pinto Soares', Thereza Cristina do Amaral', Dayane Darlles Miranda de Araújo', Vanessa Sales de Melo1, Rodrigo Marcel Valentim da Silva2,3, Patrícia Froes Meyer ${ }^{1,2}$

\begin{abstract}
Introduction: The cellulites is defined as a multifactorial disease that results in the degeneration of adipose tissue, through the stages of change of interstitial matrix, micro circulatory stasis and adipocyte hypertrophy. Objective: The objective of this research was to investigate the effect of Combined Therapy of Ultrasound and Electrotherapy (CTUE) in cellulites in women through the infrared sensor (Celluscan ${ }^{\circledR}$ ). Methods: This research is a controlled, randomized and blinded trial, consisting of 28 females, divided into 2 groups of 14 individuals with cellulites in grade II, III and IV, chosen randomly in the city of Natal/RN. Results: In the control and the treatment group, comparing between them the form and degree of the cellulites in accordance with Celluscan ${ }^{\circledR}$, showed no significant difference. Conclusion: Considering the results obtained in this study it was not possible to prove the effectiveness of CTUE, taking into account that the cellulites is a multifactorial disease, because in this case there are several factors involved, such as the triggering, the predisposing and the aggravating factors that can influence the results.
\end{abstract}

Keywords: Methods in Physiotherapy, Esthetics, Ultrasound, electrical stimulation.

\section{INTRODUCTION}

The self-image plays an important role in the lives of individuals and aesthetic disorders deserve greater attention, because they do not summarize only in physical beauty, but also mental and psychosocial health..$^{(1-3)}$

Cellulites may be defined as a multifactorial disease that results in degeneration of adipose tissue, passing through the phases of changing of the interstitial matrix, micro circulatory stasis and adipocytes hypertrophy, i.e. fat cells retain a higher lipid content, changing water balance, thus generating the increasing of the cell volume which causes compression of the vessels and the breakdown of collagen and elastin fibers, evolving to scarring and creating an "orange peel" skin

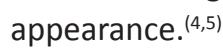

Because cellulite is a multifactorial disease, a detailed assessment is necessary, involving all the propaedeutic of anamnesis and physical examination for the effectiveness of the treatment. The infrared sensor (Celluscan ${ }^{\circledR}$ ) is a resource for determining the degree of cellulite and fluid retention level. This technology ensures a fast and accurate measurement of variations in temperature without holding the sensor to the patient skin. The equipment contains a data receiver module, temperature tip to the evaluation procedure and feedback template tape for guidance of the site to be tested. ${ }^{(5)}$

According to Meyer (2011), Dermato-functional Physiotherapy operates in cellulites using different resources, among them, we can mention the Combined Therapy of Ultrasound and Electrotherapy (CTUE), which uses ultrasound effects combined to the application of stereodynamics currents. Despite little scientific evidence on this therapy, clinical practice have shown effects of CTUE in reducing cellulite. ${ }^{(5-7)}$

The application of both therapeutic modalities at the same time and place, called combined therapy, is the most widely used combination of ultrasound (US) and some type of excited motor or polarized current. US produces mechanical, thermal and chemical effects and electrical current generates vasodilation, increased cellular exchanges and nutrition and elimination of toxins and fat degradation products. ${ }^{(7-9)}$

Thus, this study aimed to investigate the effect of combined therapy in cellulites, observe if there were changes and what were the effects of CTUE by Celluscan ${ }^{\circledR}$ analysis; describe the possible changes in the aspects of the photos comparing 
before and after treatment with CTUE and check for changes in the appearance of the skin, tenderness and pain after the use of CTUE.

This research, besides investigating the effectiveness of the combined therapy and allowing new studies, also discusses the physiological changes caused by the cellulites, which may cause health problems if not cared or prevented, demonstrating that this pathology is not only harmful in aesthetic appearance.

\section{METHODS}

This study is a controlled clinical trial, randomized and blind, approved by Research Ethics Committee of Universidade Potiguar by the number $129 / 2011$. The study will consist of 28 females, divided into 2 groups of 14 individuals, with cellulites grade II, III or IV, chosen randomly in the city of Natal/RN.

The inclusion criteria were: age ranging between 20 and 40 years old, with an average of 31 in the control group and 22 years in the treated group, weighing between 55 and 75 kilos, with cellulites (grade II, III or IV), and may be multiparous or nulliparous who were using contraceptives and were sedentary, as exclusion criteria were the patients with sensitivity disorder during treatments and do not adapt to the times and procedures of the study.

For the evaluation of the cellulites was used infrared sensor apparatus (Celluscan ${ }^{\circledR}$ ) to measure the degree of cellulites and for the treatment it was used the equipment of combined therapies Manthus ${ }^{\circledR}$ model, Ibramed brand.

The evaluated and treated area was $55.2 \mathrm{~cm}^{2}$ of the lateral sides of the thighs, called side A and D.

The applications of CTUE with treated group were according to the following parameters: Stimulus sinusoidal; Frequency $30 \mathrm{~Hz}$; Cellulite grade 3; adipose layer $3.1 \mathrm{~cm}$ 45 watts continuous; Current dose according to the sensitivity of the patient; Time of 12 minutes per member, totaling 24 minutes of therapy. The area to be treated before therapy was marked with a ballpoint pen, using the carbopol gel as coupling means. Thus, there were a total of 10 sessions, two per week, with a total of 5 weeks of treatment. At the end of five weeks the treated group which received treatment and the control group with no intervention were submitted to a new evaluation according to Celluscan ${ }^{\circledR}$.

The data analysis was performed through descriptive and inferential analysis using SPSS 19.0 (Statistical Package for the Social Science - Version 19.0). The normality test used was Kolmogorov - Smirnov (KS). For comparison between groups whose data were parametric it was applied pared t-test. In the intergroup analysis it was used independent t-test. For categorical variables was performed a descriptive analysis on the distribution of absolute and relative frequencies and used the Wilcoxon test for intragroup comparison and
Mann-Whitney test for intergroup comparison. The level of significance of $5 \%(p<0.05)$ was adopted.

\section{RESULTS}

Tables 1 and 2 refer to the characterization of control and treated groups, analyzing the clinical data: often feel heavy legs, stroke in the legs, skin appearance, nodules when pressing, pain when pressing and orange peel skin. Analyzed by the infrared sensor, for evaluation of the cellulites in the control and treated group.

Table 2 shows the data obtained from the variables of the questionnaire analyzed in the use of infrared sensor (Celluscan) for the evaluation of the cellulite treated group.

Table 03 shows the results related to the classification of the degree of cellulites provided by Celluscan, in the area bounded for evaluation and treatment of the control group.

Table 1. Distribution of absolute and relative frequencies, according to the variables of the questionnaire applied in the use of Celluscan, in the control group.

\begin{tabular}{|c|c|c|c|}
\hline Variables & & $\begin{array}{l}\text { Absolute } \\
\text { Frequency }\end{array}$ & $\begin{array}{c}\text { Relative } \\
\text { Frequency }\end{array}$ \\
\hline \multicolumn{4}{|c|}{ Often feel heavy legs } \\
\hline & Never & 7 & $50.0 \%$ \\
\hline & Spring or Summer & 7 & $50.0 \%$ \\
\hline \multicolumn{4}{|l|}{ Stroke in the legs } \\
\hline & Some & 10 & $71.4 \%$ \\
\hline & None & 4 & $28.6 \%$ \\
\hline & Total & 14 & $100.0 \%$ \\
\hline \multicolumn{4}{|l|}{ Skin appearance } \\
\hline & Moderately Elastic & 10 & $71.4 \%$ \\
\hline & Less elastic & 4 & $28.6 \%$ \\
\hline & Total & 14 & $100.0 \%$ \\
\hline \multicolumn{4}{|l|}{$\begin{array}{l}\text { Nodules when } \\
\text { pressing }\end{array}$} \\
\hline & Yes. big Nodules & 1 & $7.1 \%$ \\
\hline & Yes. small Nodules & 9 & $64.3 \%$ \\
\hline & No & 4 & $28.6 \%$ \\
\hline & Total & 14 & $100.0 \%$ \\
\hline \multicolumn{4}{|c|}{ Pain when pressing } \\
\hline & Yes & 1 & $7.1 \%$ \\
\hline & No & 13 & $92.9 \%$ \\
\hline & Total & 14 & $100.0 \%$ \\
\hline \multicolumn{4}{|l|}{$\begin{array}{l}\text { Orange peel skin } \\
\text { aspect }\end{array}$} \\
\hline & Yes. difuse & 8 & $57.1 \%$ \\
\hline & Yes. some & 6 & $42.9 \%$ \\
\hline & Total & 14 & $100.0 \%$ \\
\hline
\end{tabular}


Table 2. Distribution of absolute and relative frequencies, according to the variables of the questionnaire applied in the use of Celluscan in the treated group.

\begin{tabular}{|c|c|c|c|}
\hline Variables & & $\begin{array}{l}\text { Absolute } \\
\text { Frequency }\end{array}$ & $\begin{array}{l}\text { Relative } \\
\text { Frequency }\end{array}$ \\
\hline \multicolumn{4}{|c|}{ Often feel heavy legs } \\
\hline & Never & 9 & $64.3 \%$ \\
\hline & Spring or Summer & 2 & $14.3 \%$ \\
\hline & Frequently & 3 & $21.4 \%$ \\
\hline \multicolumn{4}{|l|}{ Stroke in the legs } \\
\hline & Some & 2 & $14.3 \%$ \\
\hline & None & 12 & $85.7 \%$ \\
\hline & Total & 14 & $100.0 \%$ \\
\hline \multicolumn{4}{|l|}{ Skin appearance } \\
\hline & $\begin{array}{l}\text { Moderately } \\
\text { Elastic }\end{array}$ & 2 & $14.3 \%$ \\
\hline & Less elastic & 12 & $85.7 \%$ \\
\hline & Total & 14 & $100.0 \%$ \\
\hline \multicolumn{4}{|l|}{$\begin{array}{l}\text { Nodules when } \\
\text { pressing }\end{array}$} \\
\hline & Yes. big nodules & 4 & $28.6 \%$ \\
\hline & Yes. small nodules & 9 & $64.3 \%$ \\
\hline & No & 1 & $7.1 \%$ \\
\hline & Total & 14 & $100.0 \%$ \\
\hline \multicolumn{4}{|c|}{ Pain when pressing } \\
\hline & Yes & 4 & $28.6 \%$ \\
\hline & No & 10 & $71.4 \%$ \\
\hline & Total & 14 & $100.0 \%$ \\
\hline \multicolumn{4}{|l|}{$\begin{array}{l}\text { Orange peel skin } \\
\text { aspect }\end{array}$} \\
\hline & Yes. difuse & 4 & $28.6 \%$ \\
\hline & Yes. some & 10 & $71.4 \%$ \\
\hline & Total & 14 & $100.0 \%$ \\
\hline
\end{tabular}

Table 03 shows that according to the $\mathrm{P}$ value, there was no statistical significance.

Table 04 shows the results related to the classification of the degree of cellulites provided by Celluscan, in the area bounded to the evaluation and treatment of the treated group.

These data in Table 4 show that there was an improvement in the degree after treatment with the CTUE, according to the infrared sensor (Celluscan).

\section{DISCUSSION}

Thus, when comparing the two groups (control and treated) was observed in the control group the number of volunteers with stroke in the legs was higher than the treated group. Considering that the average age of the control group was 31 years, according to some factors such as age, hormones, sun
Table 3. Distribution of absolute and relative frequencies of the cellulites degree classification in right and left leg, according to the treatment area in the control group.

\begin{tabular}{|c|c|c|c|}
\hline Degree of Cellulite & $\begin{array}{l}\text { Absolute } \\
\text { Frequency }\end{array}$ & $\begin{array}{l}\text { Relative } \\
\text { Frequency }\end{array}$ & p valor \\
\hline $\begin{array}{l}\text { Degree of Cellulite } \\
\text { Right Leg Initial }\end{array}$ & & & 0.10 \\
\hline Degree 1 & 2 & $14.3 \%$ & \\
\hline Degree 2 & 10 & $71.4 \%$ & \\
\hline Degree 3 & 2 & $14.3 \%$ & \\
\hline Total & 14 & $100.0 \%$ & \\
\hline \multicolumn{4}{|l|}{$\begin{array}{l}\text { Degree of Cellulite } \\
\text { Right Leg Final }\end{array}$} \\
\hline Degree 1 & 1 & $7.1 \%$ & \\
\hline Degree 2 & 12 & $85.7 \%$ & \\
\hline Degree 3 & 1 & $7.1 \%$ & \\
\hline Total & 14 & $100.0 \%$ & \\
\hline $\begin{array}{l}\text { Degree of Cellulite } \\
\text { Left Leg Initial }\end{array}$ & & & 0.12 \\
\hline Degree 1 & 3 & 21.4 & \\
\hline Degree 2 & 10 & 71.4 & \\
\hline Degree 3 & 1 & 7.1 & \\
\hline Total & 14 & 100.0 & \\
\hline \multicolumn{4}{|l|}{$\begin{array}{l}\text { Degree of Cellulite } \\
\text { Left Leg Final }\end{array}$} \\
\hline Degree 1 & 1 & $7.1 \%$ & \\
\hline Degree 2 & 11 & $78.6 \%$ & \\
\hline Degree 3 & 1 & $7.1 \%$ & \\
\hline Degree 4 & 1 & $7.1 \%$ & \\
\hline Total & 14 & $100.0 \%$ & \\
\hline
\end{tabular}

and sudden weight changes cause relaxation and stretching of the fascial system, since they are closely related to the adhesion regions of superficial fascia due to the lower adhesion areas have a lower degree of stretch and a lower volume. These elements, associated with areas of gravity, cause ptosis of soft tissue and formation of gynoid lipodystrophy.

Regard to anatomical and histological appearance, tissue with cellulite have increased number and volume of fat cells, lipoedema and lobular dissociation, thickening and proliferation of collagen fibers between adipocytes and interlobular, causing tissue engorgement, disruption of elastic fibers, lymphatic and blood vessels causing stroke. ${ }^{(8)}$

Thus, the justification for the treated group had a reduction of the edema compared to the control group, is that the application of CTUE involves the production of hyperemia, increased white blood cells and antibodies, the spasmolytic action, trophic action, analgesia, antiphlogistic, the increase in extensibility of tendons, the destruction of 
Table 4. Distribution of absolute and relative frequencies of the classification of the degree of cellulites in right and left leg, according to the delimitation area, the treated group, comparing the initial and final evaluation.

\begin{tabular}{|c|c|c|c|}
\hline & $\begin{array}{l}\text { Absolute } \\
\text { Frequency }\end{array}$ & $\begin{array}{l}\text { Relative } \\
\text { Frequency }\end{array}$ & $p$ valor \\
\hline $\begin{array}{l}\text { Degree of Cellulite } \\
\text { Right Leg Initial }\end{array}$ & & & 0.78 \\
\hline Degree 2 & 9 & $64.3 \%$ & \\
\hline Degree 3 & 5 & $35.7 \%$ & \\
\hline Total & 14 & $100.0 \%$ & \\
\hline \multicolumn{4}{|l|}{$\begin{array}{l}\text { Degree of Cellulite } \\
\text { Right Leg Final }\end{array}$} \\
\hline Degree 1 & 2 & $14.3 \%$ & \\
\hline Degree 2 & 10 & $71.4 \%$ & \\
\hline Degree 3 & 2 & $14.3 \%$ & \\
\hline Total & 14 & $100.0 \%$ & \\
\hline $\begin{array}{l}\text { Degree of Cellulite } \\
\text { Left Leg Initial }\end{array}$ & & & 0.75 \\
\hline Degree 2 & 10 & $71.4 \%$ & \\
\hline Degree 3 & 4 & $28.6 \%$ & \\
\hline Total & 14 & $100.0 \%$ & \\
\hline \multicolumn{4}{|l|}{$\begin{array}{l}\text { Degree of Cellulite } \\
\text { Left Leg Final }\end{array}$} \\
\hline Degree 1 & 1 & $7.1 \%$ & \\
\hline Degree 2 & 12 & $85.7 \%$ & \\
\hline Degree 3 & 1 & $7.1 \%$ & \\
\hline Total & 14 & $100.0 \%$ & \\
\hline
\end{tabular}

macromolecules, facilitates the reabsorption of edema, elimination macronodules and orange peel aspect in cellulites, the correction of ischemia in areas with lipodystrophy, the increased intercellular ionic exchange and improvement of lipid metabolism with the increase in lipolysis. ${ }^{(1,9)}$

The positive changes found in relation to the decrease in the level III of the cellulite, may result from the treatment with CTUE, considering that the objectives of this combination of ultrasound and stereodynamics currents are to improve the functions of lipolysis and activation of the vegetative system, greatly improving the degradation and removal of localized fat, among non-thermal effects of the US, the micromassage, the increased cell permeability, arteriolar diameter variation and cavitation. It causes an increase in the movement of intra and extracellular fluids, facilitating the removal of catabolites and the supply of nutrients. . $^{(8,9)}$

Although there is a reduction in grade III, it was observed an increase in the cellulites grade II after treatment with CTUE. Therefore, it is suggested that an involution of class III to class II may have occurred when using CTUE. The US has the characteristic of generating longitudinal vibration. As consequence, a pressure gradient is developed in the individual cells and, as result of this, the pressure changes.
Elements of the cell are forced to move, generating a micromassage movement that increases cellular metabolism, blood flow, oxygen supply, alteration of cell membrane permeability and facilitates the flow of nutrients. The increased permeability between cells, not only favors the transitional variations of interstitial and plasma lipids levels, as induces increased permeability to glucose, which facilitates the drainage of lipids by the lymphatic system and improves the redistribution of body fat. The effects of US are potentiated in the CTUE by the stereodynamics currents..$^{(10,11)}$

Subcutaneous electrical stimulation leads to reduction measurements, improves the cellulite aspect and the toning and rejuvenation of various regions of the body..$^{(12-14)}$ Such stimulation has effects on excitable tissues, generating numerous indirect effects in the body. There is also evidences of direct effects that affect the metabolism of tissues, ${ }^{(15,16)}$ increasing local blood circulation, and also those evidences are related to increasing the ATP generation by the cell. ${ }^{(14,16,17)}$

\section{CONCLUSION}

Although, according to the literature, the changes presented by patients are directly related to cellulite and the treatment applied in this study has an effect on these changes, the final results were not completely satisfactory. Hence, the results were different according to the evaluation form, suggesting the little effect of CTUE.

\section{AUTHOR'S CONTRIBUTIONS:}

IJP, TCA, DDM, VSM.: Assessment and volunteers intervention (data acquisition), wrote the paper.

RMVS, PFM: Data analysis, discussion and work guidance.

\section{CONFLICT OF INTEREST:}

The authors declare that they have no conflicts of interest.

\section{AUTHOR DETAILS}

1 Universidade Potiguar (UnP), Natal, RN, Brazil.

\section{REFERENCES}

1. Machado G C, Vieira R B, Oliveira N M L D, Lopes C R. Análise dos efeitos do ultrassom terapêutico e da eletrolipoforese nas alterações decorrentes do fibroedema geloide. Fisioter. Mov. Curitiba, 2011 jul-set;24(3):471-479.

2. Brandão, Daniele Silva Martins et al. Avaliação da técnica de drenagem linfática manual no tratamento do fibro edema geloide em mulheres. Disponível em: < http://www4.uninove.br/ojs/index.php/saude/article/ viewFile /2446/1837>. Acesso em 16 de Março de 2013.

3. Fernandes PV. Fisioterapia no Tratamento da Celulite.Disponível em: <http://www.interfisio.com.br/index.asp?fid=32\&ac=6>. Acesso em: 15 de Março 2013.

4. Avram M M. Cellulite: a review of its physiology and treatment. Journal of Cosmetic and Laser Therapy, 2004;6(4):181-185.

5. Smalls L K, Hicks M, Passeretti D, Gersin K, Kitzmiller WJ, Bakhsh A, et al. Effect of Weight Loss on Cellulite: Gynoid Lypodystrophy. Am Soc Plast Surg. 2006 Aug;118(2):510-6.

6. Callegar I. Celluscan [manual de instruções]. Disponível em: http://www. callegari.com.br/manuais/celluscan.pdf. Acesso em: 14 de Março de 2013. 
7. Meyer P F, Cavalcante J L, Patrício R A, Medeiros M L,Dantas J S C, Mendonça W C M, et al. Desenvolvimento e Aplicação de um Protocolo de Avaliação Fisioterapêutica em Pacientes com Fibro Edema Gelóide. Fisioter. Mov. 2011;1(2):31-36.

8. Francischelli M, Neto. Estudo da composição corporal e suas implicações no tratamento da hidrolipodistrofia. Rev Med Estét Soc Bras Med Estét. 2003;15:20-7.

9. Vighi M M, Guerreiro W, Lemos L V, Hein D M, Moreira F. Investigação de tratamentos mais utilizados pela fisioterapia dermato-funcional em uma clínica do município de Pelotas In: XX Congresso de Iniciação Científica:2011;RS,Pelotas: UFPEL;2011.

10. Durigan J L Q, Cancelliero K M, Reis M S, Dias C N K, Graciotto D R, da Silva $C A$, et al. Mecanismos de interação do ultra-som terapêutico com tecidos biológicos. Rev Fisioter Brasil. 2006;7(2):142-8.

11. Brescia C M, Massa D A, Cruz L B, Bomfim Júnior J V, Agne J E. Análise Morfológica do Tecido Adiposo Subcutâneo submetido a Estimulação por Ultrassom Associado à Corrente Elétrica: Estudo Piloto. Rev. kinesia, 2009mar;edição1(1):3-8.
12. Sant'Ana E M C. Fundamentação teórica para terapia combinada heccus ${ }^{\circledR}$ Ultrassom e Corrente Aussie no tratamento da lipodistrofia ginóide e da gordura localizada. Rev. Bras Ciên Estét. 2010;1(1):1-15.

13. Bassoli D. A. Avaliação dos efeitos do Ultra-som pulsado de baixa intensidade na regeneração de músculos esqueléticos com vista a aplicabilidade em clínica fisioterapêutica, 2001. Dissertação (Mestrado) - Escola de Engenharia de São Carlos, Faculdade de Medicina de Ribeirão Preto e Instituto de Química de São Carlos da Universidade de São Paulo, 2001.

14. CAMERON M H. Agentes Físicos na Reabilitação, da pesquisa a prática. 3a Ed Rio de Janeiro:Elsevier;2009.

15. Paula M R, Picheth G, Simões N P. Efeitos da eletrolipoforese nas concentrações séricas do glicerol e do perfil lipídico. Fisioter Brasil. 2007;8(1):5-9.

16. Braz G P. Sistema de eletroestimulação informatizado para tratamento da dor e para a reabilitação neuromuscular. [dissertação]. Florianópolis: Universidade Federal de Santa Catarina;2003.

17. Macedo A C B, Simões ND. Aplicação de estimulação elétrica de baixa intensidade no tratamento de úlceras varicosas. Fisioter Mov. 2007;20(3):25-33. 